\title{
Kilder til forskningsbasert kunnskap
}

Her får du grunnleggende kjennskap til hva som finnes av kilder til forskningsbasert kunnskap. Med kilder menes i denne sammenhengen bibliografiske databaser, elektroniske oppslagsverk, tidsskrifter og nettsteder

\section{Forfatter}

Hilde Strømme

Seniorrådgiver og bibliotekar

Folkehelseinstituttet

\section{Tilgang til kilder}

Noen kilder til forskning er gratis tilgjengelige, mens

andre krever abonnement. En del av de abonnementsbelagte kildene har alt helsepersonell i Norge gratis tilgang til via Helsebiblioteket (1). På helsebiblioteket.no finner du lenker til de aller fleste av kildene som omtales i denne artikkelen.

Merk imidlertid at mange helseforetak og utdanningsinstitusjoner abonnerer på kilder i tillegg til det som finnes i Helsebiblioteket. Derfor er det verdt å sjekke hva ditt eget fagbibliotek tilbyr.

\section{Oppsummert kunnskap versus primærstudier}

Som beskrevet i artikkelen «Litteratursøking i kunnskapsbasert praksis og forskning» (2) er tilgangen på oppsummert kunnskap, eller sekundærlitteratur, blitt veldig god de senere årene. 
Kunnskapspyramiden, tidligere også kalt S-pyramiden, beskriver ulike grader av oppsummering og kvalitetsvurdering (3-5). Når du leter etter svar, bør du starte med kilder for oppsummert kunnskap. Hvis du ikke finner svar på spørsmålet ditt i dem, søker du videre i databaser for primærstudier. Mange databaser inneholder både oppsummert forskning og primærstudier.

\section{Kilder til oppsummert kunnskap}

Høyt oppe i kunnskapspyramiden står kunnskapsbaserte kliniske oppslagsverk og kunnskapsbaserte retningslinjer. Via Helsebiblioteket har alle i Norge tilgang til to store kliniske oppslagsverk: UpToDate og BMJ Best Practice. De inneholder oppsummert forskning om diagnose, behandling, prognose med mer for en lang rekke tilstander. Innholdet oppdateres kontinuerlig.

Andre slike oppslagsverk, som for eksempel DynaMed og Nursing Reference Center, er ikke tilgjengelige i Helsebiblioteket, men kan være det gjennom abonnement på sykehus eller ved utdanningsinstitusjoner.

Kilder til norske, danske og svenske retningslinjer samt fagprosedyrer er Helsebibliotekets retningslinjebase (6), Nettverk for kunnskapsbaserte fagprosedyrer (7), Helsedirektoratet (8), Sundhedsstyrelsen (9) og Socialstyrelsen (10). En av de beste kildene til engelskspråklige retningslinjer er National Guideline Clearinghouse (11).

Videre nedover i kunnskapspyramiden finnes systematiske oversikter. Systematiske oversikter er oversiktsartikler der forfatterne har brukt systematiske metoder for å finne, vurdere og oppsummere alle relevante studier om et emne (12, s. 135). 
En av de viktigste kildene til systematiske oversikter er The Cochrane Library, som blant annet inneholder de systematiske oversiktene som lages av The Cochrane Collaboration.

Epistemonikos er en forholdsvis ny database for systematiske oversikter. De som står bak Epistemonikos, gjør regelmessige søk i en lang rekke kilder, blant annet The Cochrane Library, for å finne systematiske oversikter, som så inkluderes i

Epistemonikos. Vær likevel oppmerksom på at du ikke nødvendigvis finner alle Cochrane-oversikter i Epistemonikos (13), og du bør derfor søke i begge.

I tillegg til disse spesialbasene for systematiske oversikter finnes en rekke databaser som har både primær- og sekundærlitteratur, for eksempel MEDLINE og CINAHL, som beskrives nedenfor.

Sekundærtidsskrifter er tidsskrifter som kvalitetsvurderer og oppsummerer studier og oversiktsartikler publisert i andre tidsskrifter. Eksempler på sekundærtidsskrifter er ACP Journal Club, Evidence-Based Nursing, Evidence Based Midwifery og Evidence-Based Medicine. På Helsebibliotekets tidsskriftside finner du lenker til disse og flere andre sekundærtidsskrifter.

På Helsebiblioteket finner du også en lenke til McMasters pyramidesøk. Der kan du søke samtidig i flere kilder, blant annet BMJ Best Practice, UpToDate, The Cochrane Library og ACP Journal Club. Treffene blir sortert etter kunnskapspyramiden med oppslagsverk først og primærstudier til slutt.

I McMasters pyramidesøk kan du kun gjøre enkle tekstordsøk, og du får ikke benyttet deg av de avanserte søkemulighetene som finnes i de enkelte kildene. Likevel er denne søkemotoren nyttig for å orientere deg om et tema og for å gjøre raske oppslag når du ikke har tid til å gjøre mer systematiske søk. 


\section{Kilder til primærstudier}

Hvis søket i kilder for oppsummert kunnskap ikke gir svar på spørsmålet ditt, eller den oppsummerte kunnskapen du finner, ikke er helt oppdatert, bør du fortsette søket i kilder til primærstudier.

Hvis du leter etter primærstudier som kan gi svar på spørsmål om effekt av tiltak, bør du først søke i Cochrane Central Register of Controlled Trials (Trials), som er en delbase i The Cochrane Library. I Trials finnes kun randomiserte kontrollerte studier, som regnes som det beste studiedesignet for å gi svar på spørsmål om effekt (12, s. 114-8).

I tillegg, eller hvis spørsmålet ditt ikke handler om effekt av tiltak, bør du søke i en eller flere av kildene nedenfor. Disse er tradisjonelle bibliografiske databaser som registrerer innholdet i ulike tidsskrifter. I tidsskrifter publiseres både primær- og sekundærlitteratur; det er derfor også mulig å finne systematiske oversikter i dem.

MEDLINE/PubMed er den mest brukte databasen i medisin og helsefag. Den registrerer innholdet i mer enn 5600 tidsskrifter på 40 språk. Databasen produseres av National Library of Medicine i USA og tilbys via ulike leverandører. Via Helsebiblioteket får du tilgang til både MEDLINE fra leverandøren Ovid og gratisversjonen PubMed. Måten man søker på, er forskjellig i disse to, men innholdet er for det meste det samme - så velg den du liker best.

Databasen Embase har spesielt god dekning på områdene farmakologi og generell folkehelse. I PsycINFO og PubPsych finner du artikler innenfor psykologi, psykiatri og tilgrensende fagområder. AMED (Allied \& Complementary Medicine Database) dekker i tillegg til alternativ behandling flere tidsskrifter innen fysio- og ergoterapi som ikke dekkes av andre databaser. 
CINAHL (Cumulative Index to Nursing and Allied Health Literature) registrerer innholdet i snaut 3000 tidsskrifter innen sykepleie og andre helsefag, som blant annet fysio- og ergoterapi. SveMed+ registrerer innholdet i skandinaviske medisinske og helsefaglige tidsskrifter. Den er den beste kilden vi har til artikler på skandinaviske språk og om skandinaviske forhold.

\section{Hvordan søke i kildene?}

Både innhold og søkemåte varierer i de ulike kildene nevnt over. I artikkelen «Litteratursøking i kunnskapsbasert praksis og forskning» (2) finner du en del generelle tips som gjelder for mange av kildene. Mer spesifikke veiledninger for hvordan du søker i databaser som for eksempel The Cochrane Library, PubMed, Ovid-baser (MEDLINE, Embase, PsycINFO) og CINAHL, finner du lenker til under «Hjelp og veiledning» på Helsebiblioteket.

De fleste av disse veiledningene er laget og oppdateres av UBO: Universitetsbiblioteket, Medisinsk bibliotek. Det kan også være lurt å delta på søkekurs eller få hjelp av en bibliotekar til å søke.

\section{Kritisk vurdering}

Du bør alltid foreta en kritisk vurdering av den litteraturen du finner (12, kap. 4, 14). Dette gjelder særlig for primærstudier, men også sekundærlitteratur som systematiske oversikter, fagprosedyrer og retningslinjer må vurderes kritisk. Det du bør se etter når du kritisk vurderer sekundærlitteratur, er om forfatterne har brukt en systematisk metode for å finne, kritisk vurdere og oppsummere kunnskapen. 
Vær spesielt oppmerksom på at ikke alle retningslinjer og fagprosedyrer kvalifiserer til en plass høyt oppe i pyramiden. DiCenso og medarbeidere sier følgende om Clinical Practice Guidelines (CPGs) i artikkelen om kunnskapspyramiden (5): «[R]eaders should keep in mind that not all CPGs are created equal - be sure that the CPG is current and that the recommendations are evidence-based (i.e., accompanied by levels of evidence).»

\section{En verden i stadig endring}

Kildene som er beskrevet over, og rekkefølgen man bør bruke dem i, gir et bilde av tilstanden i 2018. Utviklingen går imidlertid raskt innenfor alle fagområder, og det kan skje store endringer på kort tid. For å holde deg oppdatert er det smart å besøke Helsebiblioteket og/eller ditt eget fagbibliotek med jevne mellomrom.

Artikkelen er en oppdatering av en artikkel om bibliografiske baser publisert i Sykepleien Forskning i 2008 (1).

\section{Referanser}

1. Helsebiblioteket. Helsebiblioteket. Oslo:

Folkehelseinstituttet [sitert 27.04.2018]. Tilgjengelig fra: http://www.helsebiblioteket.no/.

2. Strømme H. Litteratursøking i

kunnskapsbasert praksis og forskning. Sykepleien Forskning. 2017. Tilgjengelig fra:

https://sykepleien.no/forskning/2017/02/litteratursokin g-i-kunnskapsbasert-praksis-og-forskning (nedlastet 15.05.2018).

3. Alper BS, Haynes RB. EBHC pyramid 5.0 for accessing preappraised evidence and guidance. Evidence-Based Medicine. 2016;21(4):123. 
4. Kunnskapsbasertpraksis.no. Kildevalg

[internett]. Oslo: Folkehelseinstituttet; 07.06.2016

[sitert 26.04.2018]. Tilgjengelig fra:

http://www.helsebiblioteket.no/kunnskapsbasert-

praksis/litteratursok/kildevalg.

5. Dicenso A, Bayley L, Haynes RB. Accessing

pre-appraised evidence: fine-tuning the $5 \mathrm{~S}$ model into a 6S model. Evid Based Nurs. 2009;12(4):99-101.

6. Helsebiblioteket. Retningslinjer og veiledere [internett]. Oslo: Folkehelseinstituttet [sitert 27.04.2018]. Tilgjengelig fra:

http://www.helsebiblioteket.no/retningslinjer.

7. Helsebiblioteket. Fagprosedyrer [internett].

Oslo: Folkehelseinstituttet [sitert 27.04.2018].

Tilgjengelig fra: http://www.fagprosedyrer.no.

8. Helsedirektoratet. Nasjonale faglige

retningslinjer. Veiledere, prioriteringsveiledere og pakkeforløp kreft [internett]. Oslo: Helsedirektoratet [sitert 27.04.2018]. Tilgjengelig fra: https://helsedirektoratet.no/retningslinjer

9. Sundhedsstyrelsen. Nationale Kliniske Retningslinjer (NKR) [internett]. København: Sundhedsstyrelsen [sitert 27.04.2018]. Tilgjengelig fra: https://www.sst.dk/da/nkr.

10. Socialstyrelsen. Nationella riktlinjer [internett]. Stockholm; Socialstyrelsen [sitert 27.04.2018]. Tilgjengelig fra:

http://www.socialstyrelsen.se/riktlinjer/nationellariktli njer.

11. Agency for Healthcare Research and Quality. National Guideline Clearinghouse [internett]. Washington D.C.: U.S. Department of Health and Human Services [lest 27.04.2018]. Tilgjengelig fra: https://www.guideline.gov/. 
12. Nortvedt MW, Jamtvedt G, Graverholt B, Nordheim LV, Reinar LM. Jobb kunnskapsbasert! En arbeidsbok. 2. utg. Oslo: Akribe; 2012.

13. Strømme H, Straumann GSH, Kirkehei I, Heintz M, Hafstad E. Searching for systematic reviews: Can Epistemonikos replace The Cochrane Library? Konferanse på 15th EAHIL Conference; Sevilla 11.06.2016. Tilgjengelig fra: http://www.bvsspa.es/eahil2016/wpcontent/uploads/2016/05/G3.pdf

14. Kunnskapsbasertpraksis.no. Kritisk vurdering [internett]. Oslo: Folkehelseinstituttet [sitert 27.04.2018]. Tilgjengelig fra: http://www.helsebiblioteket.no/kunnskapsbasertpraksis/kritisk-vurdering. 